\title{
“Trench Town Rock": Reggae Music, Landscape Inscription, and the Making of Place in Kingston, Jamaica
}

\author{
Kevon Rhiney ${ }^{1}$ and Romain Cruse ${ }^{2}$ \\ ${ }^{1}$ Department of Geography and Geology, University of the West Indies, Mona, Kingston 7, Jamaica \\ ${ }^{2}$ Department of Geography, University of the West Indies, St. Augustine Campus, Port of Spain, Trinidad and Tobago
}

Correspondence should be addressed to Kevon Rhiney, kevon89@hotmail.com

Received 17 June 2012; Accepted 10 December 2012

Academic Editor: Adrian G. Aguilar

Copyright ( $\odot 2012 \mathrm{~K}$. Rhiney and R. Cruse. This is an open access article distributed under the Creative Commons Attribution License, which permits unrestricted use, distribution, and reproduction in any medium, provided the original work is properly cited.

\begin{abstract}
This paper examines place inscriptions in Trench Town, Jamaica, and explores the ways these are used to reinforce, shape, or challenge dominant images of this inner-city community. On one hand, Trench Town is like many of its neighbouring communities, characterised by high levels of poverty, unemployment, political and gang violence, derelict buildings, and overcrowded homes. On the other hand, Trench Town is iconic and unique as it is recognised worldwide for being the birth place of reggae music and home to a number of well-known reggae artists including reggae superstar Bob Marley. Today, Trench Town's landscape is filled with inscriptions reminiscent of its rich cultural past. Linked to this is a conscious effort by its residents to identify themselves with reggae music and to recapture and sustain the positive legacies that have made the community popular. This is manifested in the numerous murals, statues, and graffiti seen throughout the community evoking past images of reggae music icons such as Marley and Tosh alongside renowned black leaders such as Marcus Garvey. These inscriptions are conceived as texts and are seen as part of a broader discourse on issues relating to urban spatial identity, commoditisation, exclusion, struggle, resistance, and change.
\end{abstract}

\section{Introduction}

Research has long been focused on the particular ways places are represented and regulated as well as how particular places encapsulate, communicate, and (re)shape cultural and spatial identities [1-7]. Yet still, only limited attention has been given to landscape inscriptions (e.g., graffiti, murals, signscapes, etc.) and the role these play in either reproducing stereotypes or challenging dominant images of places or group identities [8]. Landscapes are constantly "written" and inscribed with meanings. These meanings can be read or interpreted as signs or texts about the particular values, identities, beliefs, and practices evocative of a particular era, social group, landscape, place, or space [9]. An assessment of landscape inscriptions can therefore assist our understanding of the contested nature of places as well as shed light on the various geographies of power and identity that shape these places.

This paper examines landscape inscriptions in Trench Town, Jamaica, and explores the various ways these are used to reinforce, shape, or challenge dominant images of the community. Trench Town is a small inner-city community located in Kingston-the island's capital. On one hand, Trench Town is like many of its neighbouring communities, as it has long been characterised by high levels of poverty, unemployment, political and gang violence, derelict buildings, and overcrowded homes $[10,11]$. On the other hand, Trench Town is iconic and unique as it is recognised worldwide for being the birth place of reggae music and home to a number of well-known reggae artistes such as Bob Marley, Peter Tosh, and the Wailers. Today, Trench Town's landscape is filled with inscriptions reminiscent of its rich cultural past. Linked to this is a conscious effort by some of its residents to identify themselves with reggae music and to recapture and sustain the positive legacies that have made the community popular. This is manifested in the numerous murals, statues, and graffiti seen throughout the community invoking past images of reggae music icons such as Marley and Tosh alongside renowned black leaders like Marcus Garvey. These inscriptions are conceived here as texts 


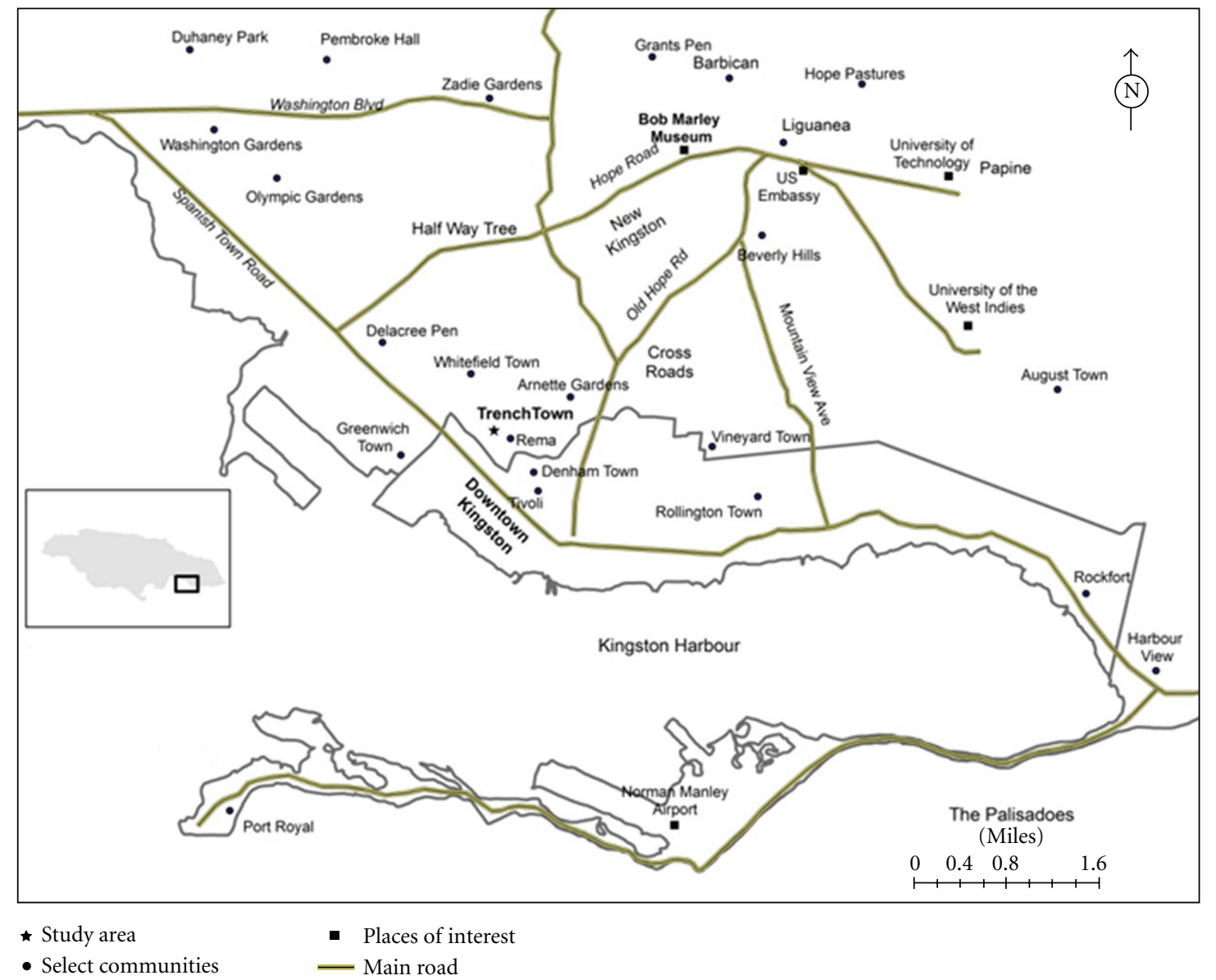

Figure 1: Location Map of the Trench Town community, Kingston.

and are seen as part of a broader discourse on issues relating to urban spatial identity, commoditisation of space, spatial exclusion, struggle, resistance, and change.

\section{A Social Geography of Trench Town}

Trench Town is located in the western section of Downtown Kingston. The community is situated in the large lowincome settlement belt that stretches south of Kingston from Duhaney Park to Rollington Town through Olympic Gardens and West and Central Kingston (Figure 1). This section of Kingston has long accounted for the highest population densities and unemployment rates $[10,12]$ and is characterised by a high incidence of poverty, political tribalism and a relatively high incidence of crime, and violence [13-15].

The spatial inscriptions seen in Trench Town are best understood through a broader urban perspective. Factors such as crime, poverty, and social exclusion contribute to the urban experience and shape urban discourse which finds expression through urban phenomena such as graffiti, murals, or even gated communities $[8,16]$. Cities can be conceived of spaces awash with multiple identities [17]. However, from a more conflict-oriented "urban arena" perspective, cities are also battle grounds for differing identities and spatial use. Contestations over urban space are a well-established discourse in the literature on urbanization, but much of this work has focused on spatial contestation and exclusion with regard to quantitatively conceived distributions of race, unemployment, housing, homelessness, population growth, and density, and so on $[10,18]$.

Qualitative approaches have shifted away from such measuring of claims to space, and are increasingly studying space knowledge, and power as intimately connected. Building on the writings of authors such as Foucault [2], we are interested in the particular ways power is manifested and contested in space by this marginalized inner-city community. We argue that power is manifested not only through the use of "spatial strategies" [3] or "disciplinary diagrams" [2] of surveillance and control by those in power but also through the spatial and discursive tactics of marginalized groups. This shift in emphasis also entails broadening the focus from struggles over control of access to and uses of spaces and places, to include the cultural politics of symbolic struggles over the meanings of places and sociospatial boundaries [12].

2.1. The Making of Trench Town. Trench Town can be regarded as one of Jamaica's most ambitious social engineering exercises-a cluster of homes with cedar doors and windows and gable roofs built around courtyards with 
communal bathrooms and kitchens. The housing project came out of a necessity to provide low cost housing to Kingston's rapidly increasing urban population and the increasing prevalence of squatter settlements. Totalling only 60,000 people in 1900, Kingston's population had reached 380,000 in 1960 (a sixfold increase). Kingston's population more than doubled between 1943 and 1970, with the rate of growth peaking in the 1950 s at 3.2 percent per annum (twice the national average at the time) $[11,19]$. Most of this growth was accounted for rural to urban migration. An increasing number of these migrants were forced to settle in the shanty towns and squatter settlements that had emerged along the city's outskirts and along the fringe of the tenement area of West Kingston. Clarke [10] described the squatter settlements as consisting of one-room huts constructed from packing cases and fish barrels, cardboard, and polythene and having few public amenities if any at all.

Trench Town, formerly known as Trench Pen, was a thirty-three-acre cattle estate located near downtown Kingston. Although it is a common misconception that the name "Trench" was derived from the large open sewer that runs through the middle of the community, Trench Town obtained its name in the late 18th Century after its owner James Trench, a prominent Irish immigrant who at the time, was utilising the vast area of land to rear livestock [20]. Trench Pen remained under private ownership until 1910, when the last surviving member of the Trench family passed away. Trench Pen was later placed under the responsibility of the general administrator Mr. Nethersole who immediately appointed a management team to organize what had become a rapidly growing community intertwined with peripheral shanty towns.

By the 1930s, Trench Town had become a fairly established settlement situated within close proximity to some of Kingston's most depressed squatter communities. Patterson [21] in his novel "The Children of Sisyphus" described the extremely harsh and insanitary living conditions residents of the "Dungle" had to endure-one of the first squatter settlements that had emerged in West Kingston that was also used for dumping garbage. Trench Town later became a fully fledged township when the colonial government initiated a major project through the then Central Housing Authority (CHA) to convert the approximately 200 acres of vacant land into a model township that comprised a range of owneroccupied and rental housing solutions. By then, Trench Town and the western section of Kingston in general had become a preferred site for rural migrants due to its close proximity to the market district of downtown Kingston and the vast tracts of unoccupied lands. In fact, the Trench family had already started to rent pieces of the estate to the wave of rural migrants that ventured to Kingston in search of job opportunities prior to 1910.

Most of the new housing developments in Trench Town during the 1950s and 1960s (popularly known as "government yards") consisted of one- or two-storey concrete buildings, built around a common courtyard with communal cooking and bathing facilities and a standpipe for accessing potable water. Each block comprised several small living quarters opening onto the shared courtyards.
Though these housing schemes were intended to serve as a model for low-income housing development in the newly independent nation state, the units that were eventually constructed were far from perfect. Due to a shortage of state funding for instance, no sewage system was initially set up for the community. As a result, the improper disposal of household waste including human refuse in nearby lands was a common practice among community residents [20].

West Kingston and Trench Town in particular became unstable and dangerous from the early 1970s onwards. The large concentration of mostly disenfranchised and impoverished households made the general area a prime target for the two rivalling Jamaican political parties-the People's National Party (PNP) and the Jamaica Labour Party (JLP). As early as the mid-1960s, new housing units were constructed to accommodate increasing numbers of political supporters of whichever party was in power. This soon escalated into a spate of politically-motivated violence between supporters of the two rivalling parties beginning in the mid-1970s [15]. The violence continued way into the 1990s, claiming the lives of hundreds of inner-city youth residing in the highly impoverished neighbourhoods of West Kingston-including communities like Trench Town, Rema, Arnette Gardens, Denham Town, and Tivoli. Some insiders' books illustrate the extent of the violence of those times, starting with Phillip Baker's "Blood Posse" [22] and Vivian Blake's (auto)biography on the infamous Tivoli Garden's "Shower Posse" gang [23] — both underlining the parasitic and highly violent nature of Jamaican politics.

Trench Town's location places it in a peculiar situation. As Eyre [13] points out the community horrendously sits on the "frontline" (locally known as Berlin Wall, Dead Man Gulch, or No Man's Land) that separates two sets of opposing political enclaves, generally known as "garrison" communities. These garrison communities are a major and unique feature of Jamaican politics and are the results of more than fifty years of political favouritism and coercion between the two major political parties and their affiliated gangs [11, 24]. Figueroa and Sives [25] define the term "garrison" as representing in its most extreme form "a totalitarian social space in which the options of the residents are largely controlled." Eyre [13] described this as a "very real [political] frontier between the two [enemy] territories [that] zigzags through the most densely populated section of Kingston." According to Figueroa and Sives [15] this "frontier" is just as dynamic and mobile as the garrison themselves, and the buffer community of Trench Town has alternatively been a JLP garrison (during the 1940's and the 1989 general election), a split garrison with one side strongly PNP and another side strongly JLP (during the 1950 's) and a mixed community where vote patterns were more heterogeneous (Figure 2) [26].

The political warfare that has ravaged the community has had two distinct effects. On one hand, Trench Town's physical landscape has rapidly deteriorated. The once modern housing project has been reduced to a cluster of dilapidated buildings, some of which have been abandoned and left in ruins. As everywhere else in the Third World the structural adjustment programmes undertaken by the 


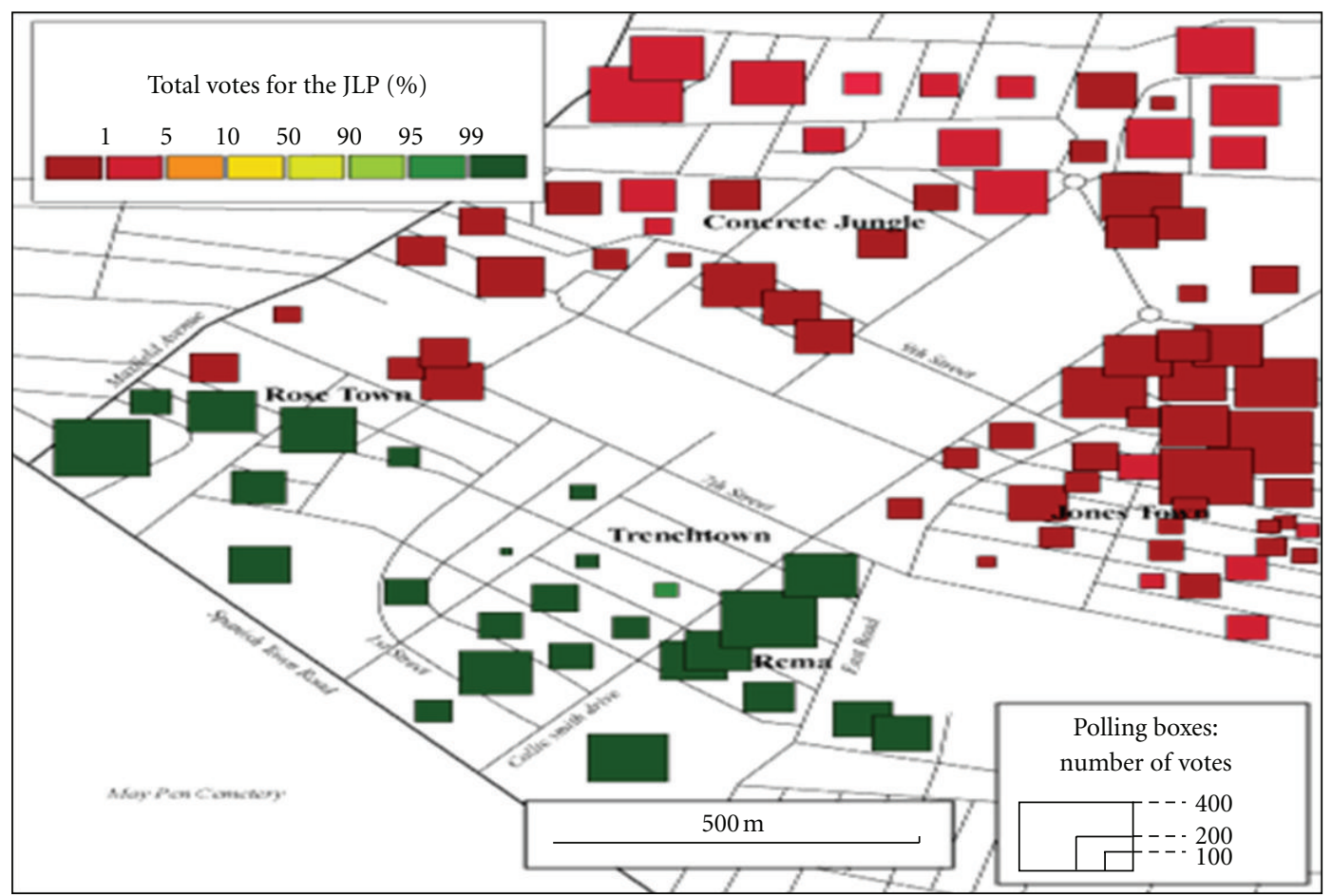

FIgURE 2: Political borders in parts of West Kingston, 1989 elections. Sources: Electoral Report, 1989. Map: Romain Cruse, 2008.

Jamaican government since the late 1970s compounded the community's problems $[27,28]$. Sewage-less shanties comprised predominantly of wood and zinc mushroomed in between the yards themselves and corner shops at the intersections. The negative effects of the austerity measures undertaken by the Jamaican government over the years were nowhere as dramatic as in Kingston's ghettoes-maybe except for rural agricultural communities-especially in Trench Town where gang warfare and the stigma of garrison politics were discouraging any form of investment [29].

On the other hand, like the case of other neighbouring communities such as Olympic Gardens (birthplace of Jamaican dub music), the political pressure and oppression faced by the residents of Trench town have contributed to the emergence of a famous (sub)cultural (r)evolution of the Jamaican musical culture where Ska and Rocksteady made way for a more politically confrontational and resistant form of Reggae music [30].

2.1.1. The Emergence of Reggae Music and Its Importance to Trench Town. It should be noted that with the advent of reggae in the 1960s [31], Jamaican music exploded on the international scene in an unprecedented way [30]. Before that, ska enjoyed popularity outside of Jamaica, especially in England where a large migrant population had settled. By the end of the 1960s however, reggae artists like Jimmy Cliff, Bob Marley, Marcia Griffiths, Desmond Dekker, and the Aces were beginning to score consistently on the British pop charts [30]. As a result of this, international record companies became interested in the potential of reggae to infiltrate the large and untapped US and European markets.
The making of the Wailers' album "Catch A Fire" in 1972 signalled reggae's ascension in international pop music [30]. Over the next few years, more and more Jamaican reggae artists started to tap into the overseas markets evident through increases in record sales, signings, and overseas tours. By the mid-1970s, reggae became the Third World's most influential pop music form [30]. However, by this time Marley's success and international popularity had superseded everyone else [32]. In 1975 Bob Marley made his international breakthrough with his first hit single outside Jamaica dubbed "No Woman No Cry", from the "Natty Dread" album. This was soon followed by his breakthrough album in 1976, "Rastaman Vibration," which spent a total of four weeks on the United States Billboard Top 100 music chart. By 1978, Marley received the distinguished Peace Medal of the Third World from the United Nations for speaking out against oppression, poverty, and violations against human rights through his music —of particular note, the stance Marley took against Apartheid in South Africa.

Despite its international appeal, it is probably fair to say that reggae is largely an urban phenomenon. Many of the lyrics are related to the urban experience and centred on issues related to race, class, poverty, resistance, and change. Trench Town has been accredited for its significance in the creation of this popular musical art form. Aside from Bob and the Wailers, Trench Town has produced several local and world renowned reggae artistes. The fact is that music provided one of the few avenues for members of the inner city to advance themselves. As such, people in the inner city produced a subculture of entertainment. Not much has changed today, as the majority of dancehall artistes in 
Jamaica still originates from the inner-city communities of Downtown Kingston [12].

\section{Exploring Trench Town's Landscape Inscriptions}

More and more writers are starting to view "place" as a product of sociocultural processes $[8,33-35]$ rather than simply a bounded geographic space. The latter accords primacy to the spatial economy of cities and places attention on the logistics of urban policy, planning, and administration. The former, views cities and their associated landscapes, as spaces of representation or narratives that are equally mediated and shaped by a combination of cultural, political and economic forces [36].

Increasingly, place is being seen as both constitutive of, and constituted by social relations [37-41]. Massey [42] argues that places are constantly being materially and imaginatively constructed by different human agents and actors and therefore do not have single, unique identities. Instead, places are full of internal conflicts and are highly contested. If this is true, then more attention should therefore be given to individuals' attachment to and perception of particular places. Places are therefore viewed as sites of intersecting social relations, identities, meanings, and collective memory $[9,43]$.

Landscape inscriptions, like any other spatial strategy and form, allow us to elicit, if even partially, the importance of place to people's sense of identity. This paper thus seeks to build on this growing body of literature on placing-making and place politics, by looking at the various inscriptions seen throughout Trench Town's landscape and examining their role in conjuring up positive images of the community's rich heritage as the birthplace of reggae music as opposed to run-down violent-riddled inner-city community. The paper is informed by substantial qualitative and ethnographic research extending between November 2008 and July 2010. Numerous trips were made to the community over the time period wherein mostly informal interviews were carried out with residents of the community. Interviews were also conducted with representatives at the Trench Town Culture Yard Museum and a number of other community-based and faith-based organisations. Voluntary work was also done at the Trench Town Comprehensive High School by the two researchers in Fall 2009. This provided the researchers an opportunity to engage with staff and students (most of whom resided outside Trench Town in neighbouring innercity communities), to get their impression of the community particularly in terms of its association with crime and violence.

Using Trench Town as a case in point, the remainder of this paper explore the role of landscape incriptions in the social construction of place, power, and identity. These inscriptions (whether murals, monuments, graffiti, or signscapes) are conceived here as texts and are seen as innately communicative and encoded with meanings. These meanings can be "read" or interpreted as signs about the particular values, identity, beliefs, and practices evocative of the place and its associated past. However, texts are replete

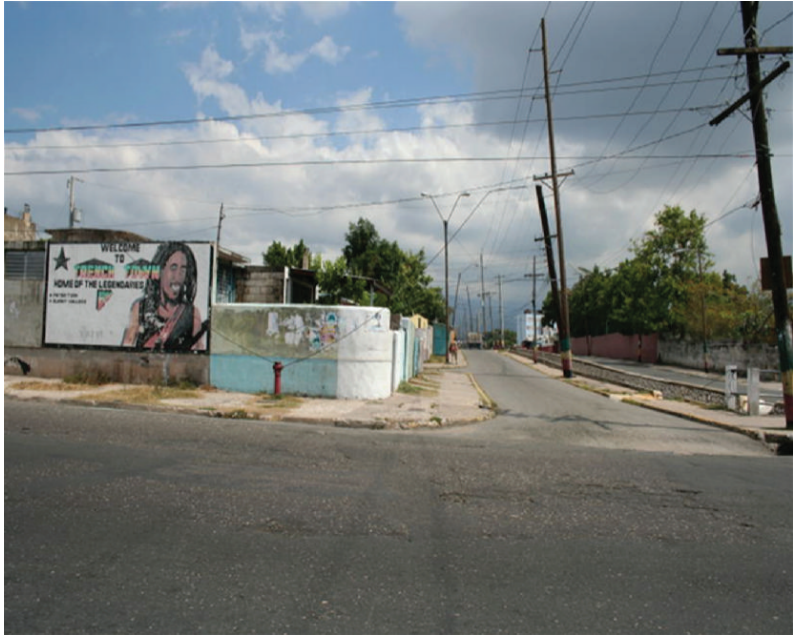

Figure 3: Mural of Bob Marley seen along the Spanish Town Road, Trench Town. Source: Cruse, 2008.

in so far as they are grounded in a locally defined social context [9]. In order to understand a text, the reader has to understand the particular context that gave rise to such text. If read properly, landscape inscriptions can uncover the cultural politics of place, as well as the various uneven geographies of power and identity. Landscape inscriptions are therefore innately political and are mediated spatially through social codes and hegemonic practices $[8,44,45]$ to produce particular senses of place and meanings.

3.1. Murals as Landscape Inscriptions. Murals are a dominant feature of Trench Town's current landscape. We observed more than 15 different murals while in the study area which were all evocative of the community's association with reggae music and past reggae icons. These murals were strategically placed at the entrance of the community and along the major thoroughfare of Collie Smith Drive. Along Spanish Town Road (which is the major corridor leading from Downtown Kingston to Spanish Town, Jamaica's second largest city) is a mural bearing the figure of Bob Marley with the caption "Welcome to Trench Town: Home of the Legendaries" (Figure 3). In the background Marley is seen smiling and playing his guitar. Below, in smaller sized captions is an incomplete listing of some famous individuals who came from the community.

This mural can simply be interpreted as a conscious effort by residents of the community to distinguish themselves from neighbouring communities. Anyone driving along Spanish Town Road without prior knowledge of the area would easily pass the community without even noticing it. Unlike their more well-off counterparts in upper St. Andrew, most of these communities do not have proper street signs or clearly defined (formal) boundaries and are generally labelled as "downtown," "ghetto," or "West Kingston". However, a deeper reading of the text sees a landscape filled with inscriptions reminiscent of the community's heritage, a past that distinguishes Trench Town and its residents from other communities in Downtown Kingston. The painting of 


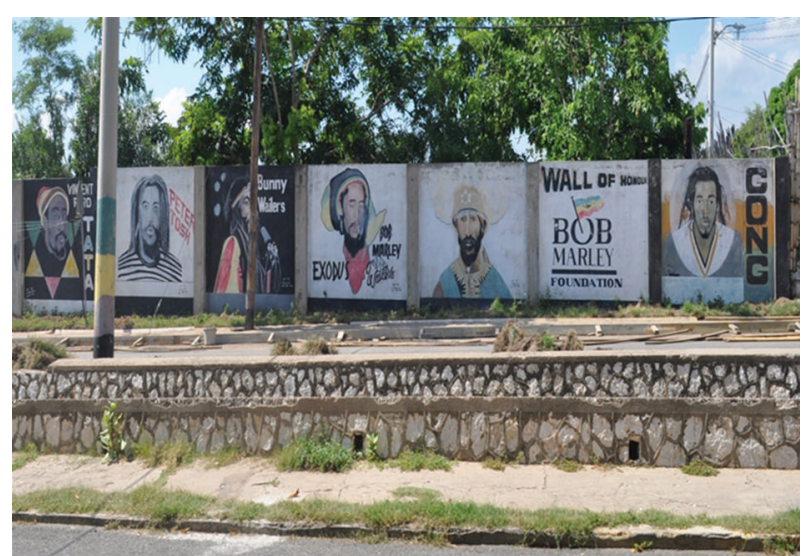

Figure 4: Wall of Honour along Collie Smith Drive, Trench Town. Source: Francis-Rhiney, 2012.

Bob Marley symbolises some of the community's members attempt to align themselves to the accomplishments of Marley and everything positive he represents.

As one enters the community one sees a line of murals depicting Marley and other accomplished reggae artistes from the area including Bunny Wailer and Peter Tosh (Figure 4). In one instance, Marley is seen smoking marijuana with his head fused in with the African continent. The mural depicts the reggae roots album "Exodus" that was produced by Bob Marley and the Wailers in 1977. It is interesting to note that Exodus was Marley's response to the politically motivated assassination attempt on his life in 1976 [46]. As such, most of the album was recorded in London while Marley was in self-imposed exile. It was regarded by many to be his best album ever produced, with several hit singles including "Jamming," "Waiting in Vain," and "One Love." In 1998, the TIME magazine named "Exodus" as the best music album of the 20th century. The album's backdrop is laden with political intrigue and rhetoric as Marley queried issues of race and class that had, by that time, become very pronounced in a newly independent and postcolonial Jamaican society [46].

While the community's attempt to align itself with the image of Bob Marley is quite understandable, it can also be interpreted as playing into place and identity politics. Justifiably, any discussion on the life accomplishments of Bob Marley would be incomplete without looking at his connection with Trench Town. Likewise, any discussion on Trench Town would be partial if one neglects Marley's legacy - arguably the most prominent person to have lived in the community.

Trench Town is said to have inspired many of Marley's songs including "Trench Town," "Trench Town Rock," "No Woman No Cry," "Concrete Jungle" and "Natty Dread" [47]. However, by singling out Marley, the community runs the risk of playing into popular conceptions of the place. Throughout most of the literature and electronic media, Trench Town has been narrowed down to its association with the life and legacy of Robert Nesta Marley. For the most part, the literature seems to romanticise the fact that someone as accomplished and internationally renowned such as Marley could grow up in such an impoverished and volatile innercity community, paying little attention to the wealth of other talents and artistry that came from the community before and even during the peak of Bob's career. No doubt Marley's ascendancy to international stardom helped place Trench Town on the world map. However, Marley is just one of the many other reggae artistes that came from the community, including the likes of reggae pioneer Joe Higgs, Delroy Wilson, Leroy Sibbles, Bongho Hermon, Alton Ellis, Jimmy Cliff, Ken Booth, Dean Fraser, and the I-Threes and vocal groups such as the Heptones and the Abyssinians. In order to not pay homage to these and other reggae icons the risk of painting a very skewed and "media-centred" representation of the community runs.

The promotion of local places as sites of consumption is fairly well established in the academic literature [48-52]. In fact, in an effort to drive economic growth, many cities across the world have been promoted as tourism destinations which usually involve the representation of selective imagery targeting specific groups or even including the physical modification of local places to fit a promotable image $[53,54]$. While a tremendous amount of emphasis has been placed on the role of extra-local phenomena such as the tourist gaze or the international media in the commodification and popular representation of local places $[55,56]$, the role local agents play, especially nonstate actors, in constructing particular images of places cannot be overlooked [57]. Certainly in the case of Trench Town, the inclusion of Bob Marley in the many murals strategically positioned throughout the community promotes a particular image of the community.

The murals seen in Trench Town also conjure up images of Rastafari culture and belief. The painting of Emperor Haile Selassie (Figure 5) can also be seen beside images of Marley, Peter Tosh, and Bunny Wailer. Additionally, Marijuana, which is used by most Rastafari in their cultural/spiritual practices, and Africa, which represents the "mother land," form dominant images in the paintings. The colours red, green, and gold are also emphasised as they represent the colours of the Ethiopian flag. Bob Marley and to a greater extent Trench Town are as central-as other places like the Pinacle and Wareika Hill-to any discussion on Rastafari culture. Bob himself was a staunched Rastafari and West Kingston (Trench Town in particular) was known to be the home and refuge of some of the first set of Rastafarians in Jamaica, including the likes of Mortimo Planno, Bongho Herman, and Leonard Howell.

These inscriptions also link into a much broader discourse on the importance of the Rastafari culture and its influence on reggae music and Jamaican identity [58-60]. The ascendancy of reggae was parallel to the increasing popularity of Rasta which reached its peak in the 1970s. In summarising this situation, Stolzoff [30] asserts:

While many of the leading artists had long been influenced by Rastafari, in the reggae era a great majority of these Rasta-identified performers publicly declared their new identity and conversion to Rastafari (page 95). 


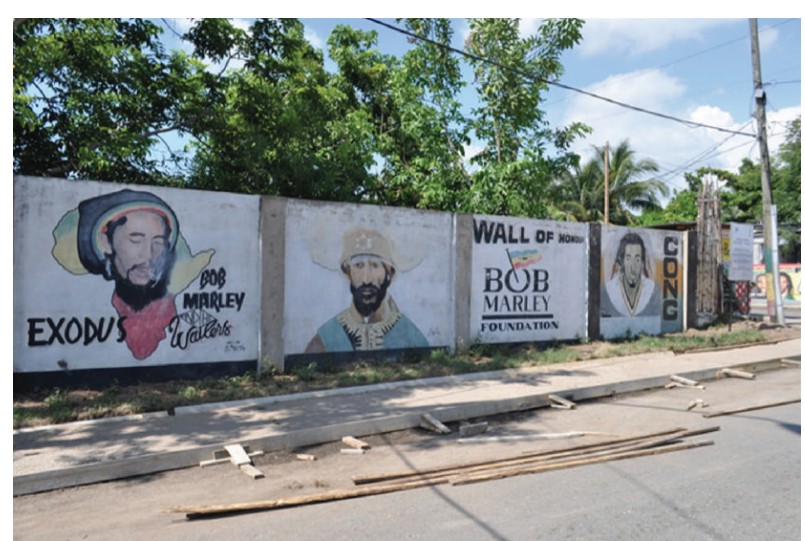

FIgure 5: Painting of Emperor Hailie Selasie, Trench Town. Source: Francis-Rhiney, 2012.

The rise of the Rastafari movement in Jamaica was linked in part (and probably still is) to the marked racial and socioeconomic divisions that were evident in the society, especially in Kingston [10, 11]. In time this resistant culture would find creative outlets in the rise of reggae music, and dancehall to a lesser extent $[61,62]$. Reggae music and the Rastafari movement were therefore borne out of the same harsh socio-economic and political realities associated with everyday life in the ghettos of West Kingston and are arguably inseparable from each other. This would explain the appeal Rastafari had for many of the top Reggae icons during the decades of the 1970s and 1980s.

Other types of murals were seen throughout the community, mostly paying homage to political representatives and local area leaders or "dons." While these and other place inscriptions (including a range of graffiti texts) were not as pronounced and pervasive as the murals showcasing reggae icons such as Bob Marley and Peter Tosh, they were also strategically positioned. These inscriptions could be found mostly in the inner sections of the community, seemingly outside of the public's "gaze."

This was in sync with the way the area, or at least parts of it, was being showcased on one hand as an authentic replica of the Trench Town Bob Marley spoke about in his songs-an impoverished and depressed inner-city community yet free from the political stranglehold that characterises so many of downtown Kingston's garrison communities. However as one ventures further in the community it becomes increasingly apparent that Trench Town's landscape is no different from the sort of political "turfism" imbued in most of the graffiti seen throughout Kingston [8]. Numerous graffiti were seen throughout the community on both walls and zinc fences making references to the community's affiliation to either of the two major political parties. Interviews with residents confirmed that the community was in fact going through a transitional phase and was almost equally split in terms of support to both the JLP and PNP. This was in line with the results of the 2007 general elections in Jamaica which saw the JLP marginally defeating the reigning PNP at the polls after being in opposition for some 18 years.

If we should apply MacCannell's seminal work on "Staged Authenticity" here, then Trench Town is similar to many theme parks and tourist destinations around the world that are intentionally divided into a "front stage" and a "back stage" [63]. According to MacCannell [63] back stage regions comprise the private living area of residents and are strategically situated out of the reach of visitors. However, as Pearce [64] rightfully contended, visitors can, at times, access back stage areas but only under certain conditions. In the case of Trench Town, movement is largely confined to the outer sections (front stage regions) of the community along Collie Smith Drive and the top of First Street where the Trench Town Culture Yard Museum and Reading Centre are located. Access to the inner sections of the community by an outsider is largely prohibited. Entry is usually gained by means of a "guided tour" by one or two residents of the community (most often a male resident who comes highly recommended by the operators of the Culture Yard) and visitors are cautioned about taking photographs of people or their homes without prior consent.

\subsection{The Culture Yard and the Making of Place. The Trench} Town Culture Yard Museum can also be interpreted as representing another form of landscape inscription. A close look at the museum shows how much it is designed to conjure up selective images of Bob Marley and the wider Trench Town community, though in a slightly and uniquely different way from that of the murals. Like most of the murals reminiscent of the community's historical association with reggae music, the "Culture Yard" as it is popularly called is situated at the front of the community. Even though this location was not predetermined and is simply based on the tenement yard where Bob Marley spent most of his childhood and adolescent years, it is not surprising that the museum is situated in close proximity to the murals seen at the entrance of the community. The murals were reportedly commissioned by the Marley Foundation to pay homage to the contributions made by Bob Marley and other reggae icons such as Peter Tosh and Bunny Wailer to Jamaican music, as well as other important black figures such as Marcus Garvey.

The Trench Town Culture Yard was opened on February 6, 2000 (symbolic of Bob's birthday), as tribute to the yard where Marley grew up and was inspired to write many of his internationally renowned songs. The Yard is operated by a few members in the community and is geared at attracting visitors both locally and abroad. The entrance of the Museum is very simple and basic (Figures 6 and 7). The only other thing that signals that a museum does in fact exist is a sign that reads "Trench Town Culture Yard: An Inner City Heritage Tourism Product." On the sign is a drawing depicting a Rastafari with his dreadlocks colored in red, gold, and green, seemingly preparing a meal around a wood fire. Below the drawing is another set of subtitles entailing an excerpt from one of Marley's songs "No Woman No Cry." The subtitle reads "Inn [sic] a government yard in Trench Town."

The Culture Yard comprises a warren of 16 cramped rooms where Marley and his friends once lived. The tour generally entails a walk through several of these rooms. Each room is arranged slightly differently from the other. The first 


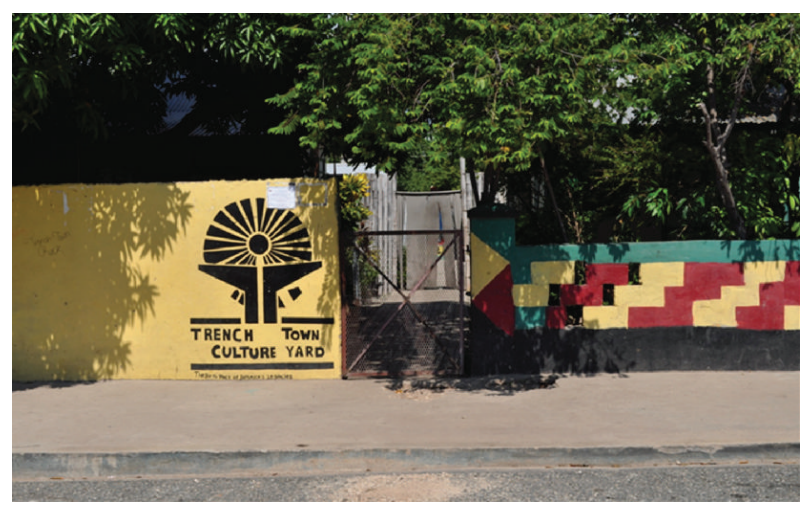

Figure 6: Entrance of Culture Yard Museum, Trench Town. Source: Francis-Rhiney, 2012.

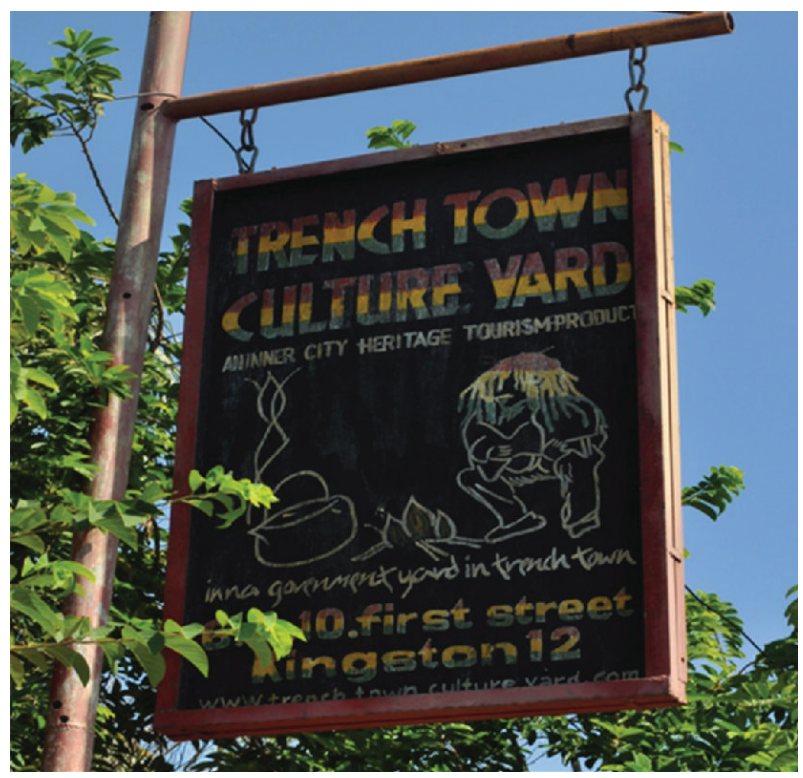

Figure 7: Sign at entrance of the Culture Yard Museum. Source: Cavell Francis-Rhiney, 2012.

room consists of past aerial photographs of the area, schematic plans of the housing scheme, and historical data on Trench Town including background information on the Trench family. The second room comprises some of Marley's memorabilia, including pictures and newspaper clippings of him and other famous persons from the community. In this room lies Marley's first guitar which is neatly placed in a glass case. One of the rooms is said to have been the home of Vincent Ford also called "Tarta." An interview with residents in the Yard revealed that Tarta is believed to have taught Bob how to play the guitar and had inspired Marley to write the words of the song "No Woman No Cry." This was also pointed out as being the main reason for the inclusion of an excerpt of the song in the sign situated at the front of the museum.

Outside, in the courtyard are the preserved remains of Marley's first vehicle-a 1970 Volks Wagen van-and an original statue of Marley that was donated to the Culture Yard by the Marley family (Figure 8 ). The Yard seems to be

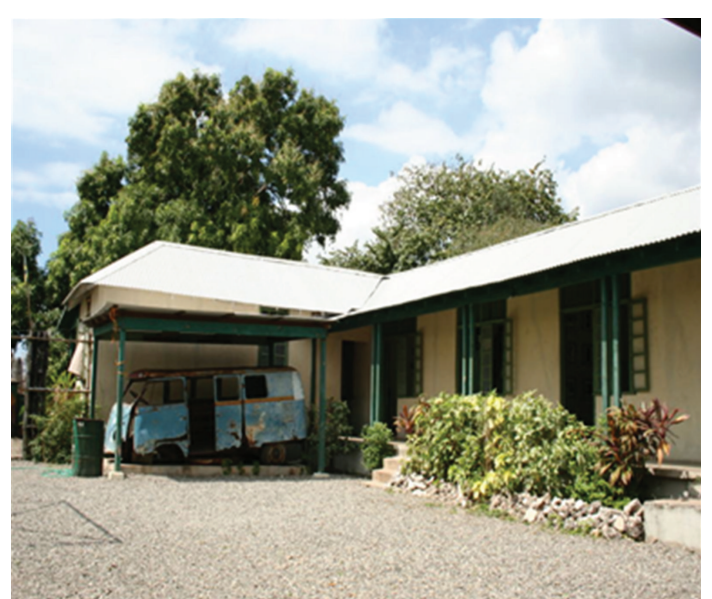

(a) Marley's 1970 Volks Wagen on display

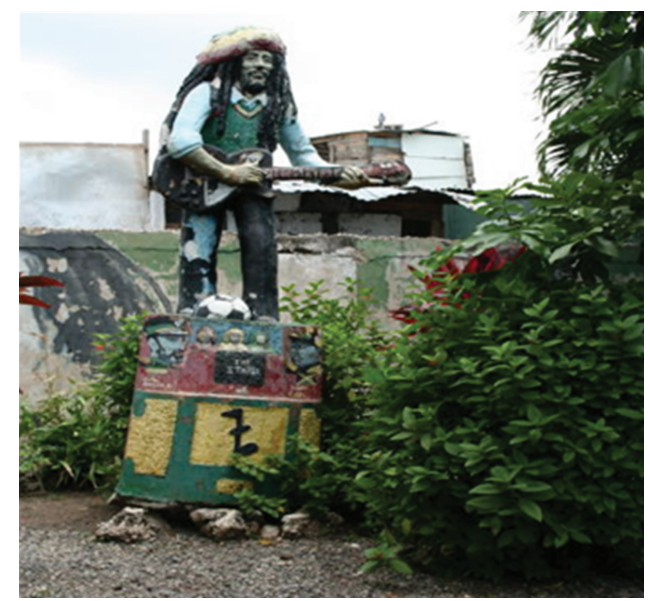

(b) Original statue of Bob Marley

Figure 8: Images from the Trench Town Culture Yard Museum. Source: Rhiney, 2009.

a regular hang-out spot for local men from the community, most of whom stated that they were unemployed. In the background one can often hear the sounds of Marley's most famous songs playing from the veranda of one of the buildings.

Overall, the Culture Yard seems to be struggling to remain open. Visitor numbers are relatively low and inconsistent. The tour is ad hoc and the Yard, though properly kept, seems wholly lacking in amenities and the infrastructure is in a dilapidated state. The residents' inability to attract visitors to the Culture Yard might be partly linked to peoples' perception of the place as being a crime-ridden inner city community. Despite a drastic reduction in crime in the community since the mid-1990s based on official records and the reassurance of local residents of visitor safety, the operators of the Court Yard reported that it is extremely difficult to attract local tour operators to visit the area.

Interviews revealed that the operators of the Culture Yard believe that the biggest threat to the survival of the museum in Trench Town is the competition presented by the Bob Marley Museum, located less than 10 kilometres away in the neighbouring parish of St. Andrew. The Bob Marley Museum 


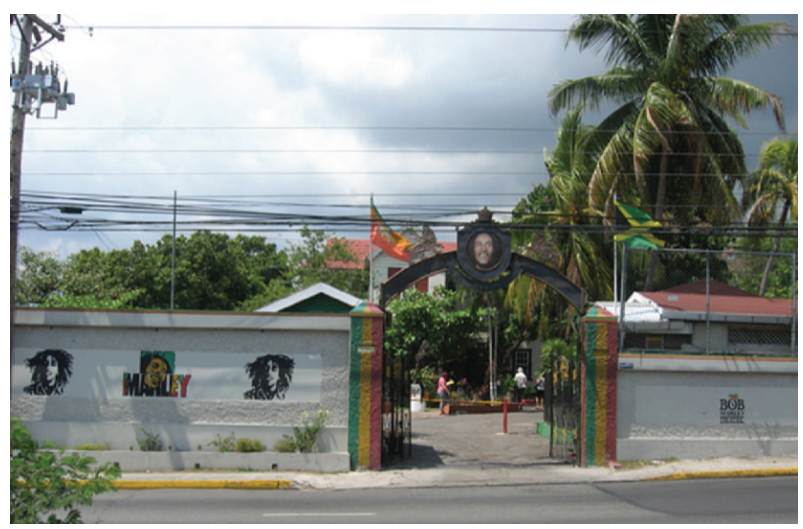

Figure 9: Entrance of the Bob Marley Museum. Source: Rhiney, 2009.

is in stark contrast to the Culture Yard in terms of physical infrastructure and visitor presence (Figures 9 and 10). The Museum is owned and operated by the Marley Foundationwhich is an affiliate of the Bob Marley Group of Companies (comprising Ghetto Youths International, Tuff Gong and the Rita Marley Foundation). The Museum, unlike the Culture Yard, was opened to the public on May 11, 1986, which commemorates the date at which Bob Marley died. Marley died of cancer at the age of 36 on May 11, 1981.

The Museum showcases Marley's posh upper St. Andrew home, located along Hope Road, one of Kingston's major thoroughfare. The house is a colonial style bungalow, with latticed windows and a marble stairway. Here, Marley rehearsed five albums and survived the 1976 assassination attempt. The package entails a well-organised tour through the museum. With a culmination of artefacts, memorabilia, writings, newspaper clippings, and photographs (including a life size hologram of Bob) each room portrays the life and achievements of Bob Marley. The Museum also houses a theatre and a gallery, a library, a restaurant, and a gift shop and is arguably Kingston's top tourist attraction. On any given day, the Museum is bound to be filled with visitors, a significant number of whom reportedly travelled to Kingston from distant resort towns such as Ocho Rios and Montego Bay situated along the island's north coast just to visit Marley's Hope Road residence.

Despite the stark differences observed between these two places, they share a few things in common. One of the most interesting and striking similarities between the two museums was in the artefacts they both chose to highlight. Both properties had one of Bob's former vehicles on display for instance. At the Culture Yard, Marley's 1970 Volks Wagen was put on display while his 1976 Land Rover was being exhibited at the Hope Road complex. Both museums also showcase a statue of Bob Marley playing one of his favourite guitars along with several other artefacts, memorabilia, newspaper clippings and photographs highlighting the artist's various accomplishments. Additionally, it was seen in a number of instances where attempts were being made at the Hope Road property to showcase Bob's connection with Trench Town. There is actually a replica of the record store Bob and his wife, Rita Marley, once owned and operated in Trench Town

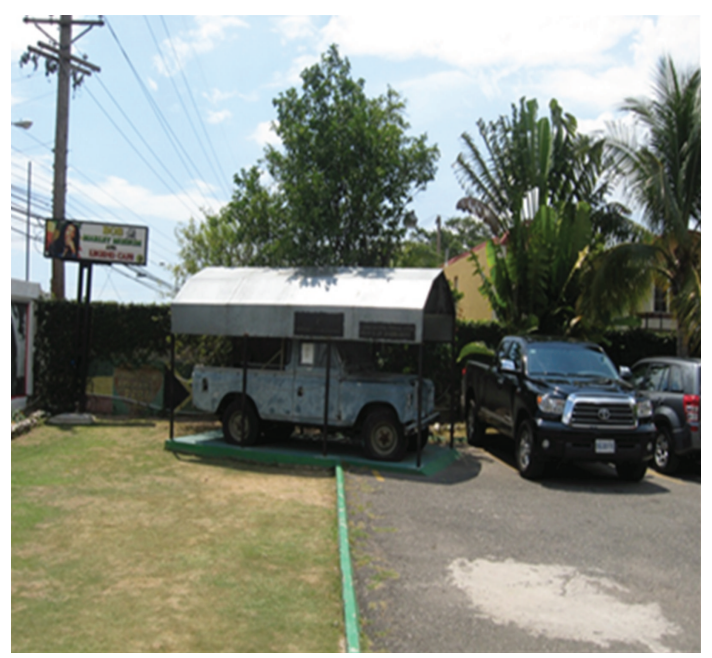

(a) Marley's Land Rover on display

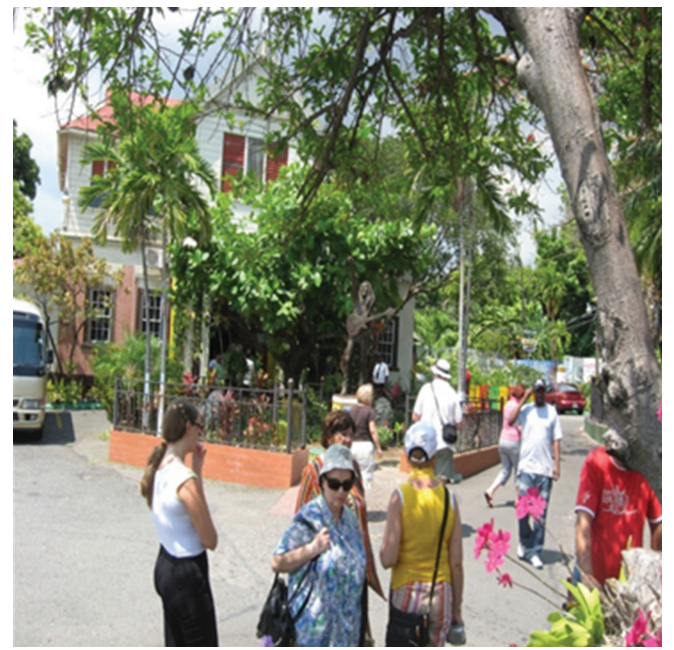

(b) Front view of the museum with Marley's statue in the foreground

Figure 10: Images of the Bob Marley Museum, Hope Road, Kingston. Source: Rhiney, 2009.

in the main museum as well as photos in the front yard depicting some of Marley's early years in the West Kingston community.

As in the case of the murals, the Culture Yard also represents a form of landscape inscription-an inscription that claims to be representative of a particular Trench Town and its contribution to Jamaican music, identity, and culture. Yet still, upon closer inspection, the Culture Yard, like in the case of the murals seen throughout the community, seemingly plays into popular conceptions and stereotypes of the place. The tremendous emphasis placed on Bob Marley and his life accomplishments effectively downplay the role and contribution of so many of Trench Town's residents. While most of these individuals were singled out, their achievements and the contributions made to the development of the community were largely understated when compared to Bob Marley. One may argue that this is indicative of the outstanding accomplishments of Marley 
and the level of international recognition his work gave to the community. Nevertheless, this can also be interpreted as either a subconscious or conscious effort by at least some members of the community to capitalize on Marley's international appeal while paying scant regard to the host of other talented individuals that have originated from Trench Town.

There also seems to be an overemphasis on Rastafari as representative of Trench Town's contribution to Jamaican music and culture. While reggae music and Rastafari are undoubtedly linked, it would be flawed to confine Trench Town's significance to reggae music solely to the Rastafari movement. Indeed, Trench Town has produced many famous reggae artistes who did not necessarily ascribe to the Rastafari movement, including the likes of Ken Booth, Joe Higgs, Alton Ellis, and Leroy Sibbles.

Another important theme emerging from this case study relates to the influence of popular cultural media such as films and music in the making of place. The interrelationship between media, cultural heritage, and tourism has been receiving increasing attention in tourism studies (see e.g., [65-68]). From classical music sites in Salzburg (Austria) and Vienna (Italy) to Beatles sites in Liverpool [69] more and more scholars have been exploring the specific role media and tourism (music tourism in particular) plays in the social construction of place. Alderman [7], for instance, examined how important Graceland-the final residence and resting place of American music icon Elvis Presley in Memphis, Tennessee-has become to modern popular American culture. Graceland is now a major cultural heritage site to both fans and non-fans of Elvis throughout the United States and from all parts of the world. Approximately 700,000 visitors reportedly tour Elvis' Graceland mansion each year, making it probably the most famous house in America, next to the White House [70]. Like Graceland, Trench Town's landscape has also been impacted by a variety of cultural media products and popular imaginations evident in its many narrations and place inscriptions. As Gibson and Connell [69, page 14] point out, there is no doubt that "Music remains a powerful presence in global mediascapes, in both the images and associations with place captured in lyrics, in connections between artists, bands or whole "scenes" and certain places."

\section{Concluding Thoughts}

The paper examines several landscape inscriptions in Trench Town and explores the various ways these are used to reinforce, shape, or challenge dominant images of the community. Trench Town, like so many of its neighbouring inner-city communities, has long been characterised by high levels of poverty, unemployment, political and gang violence, derelict buildings, and overcrowded homes [10, 11]. Yet still, Trench Town is revered around the world for being the birthplace of reggae music and home to a number of internationally renowned reggae artistes such as Bob Marley, Peter Tosh, and the Wailers.

The study found that Trench Town's landscape is filled with numerous landscape inscriptions, ranging from murals, statues, graffiti, and museum to dilapidated buildings and zinc fences. Most of these inscriptions are seen as resulting from the conscious efforts by some of Trench Town's residents to evoke images of the community's rich heritage and its overwhelming association with reggae music and reggae icons like Bob Marley and Peter Tosh. While this past distinguishes Trench Town and its residents from other communities in Downtown Kingston, these inscriptions are also interpreted as playing into place and identity politics. Though Bob Marley is arguably the most popular figure to have originated from Trench Town to date, by singling out Marley, the community runs the risk of playing into popular conceptions of the place. Throughout most of the literature and electronic media, Trench Town's significance has been confined to its association with the life and legacy of Robert Nesta Marley. No doubt Marley's ascendancy to international fame helped place Trench Town on the world map; however, Marley is just one of many other reggae artistes that grew up in the area.

The Trench Town Culture Yard Museum can also be interpreted as representing another form of landscape inscription. The museum also conjures up selective images of Bob Marley and the wider Trench Town community, though in a slightly and uniquely different way from that of the murals seen throughout the community. Similar to the murals, the Culture Yard also represents a form of landscape inscription-one that claims to be representative of Trench Town and the community's contribution to Jamaican music and culture in particular. Yet still, the Culture Yard, like in the case of the murals, seemingly plays into popular conceptions and stereotypes of the place. The tremendous emphasis placed on Bob Marley and his life accomplishments, for instance, effectively downplay the role and contribution of so many other Reggae icons including Ken Booth, Alton Ellis, Leroy Sibbles, Peter Tosh, and Bunny Wailer to name some.

To sum up, we contend that landscape inscriptions, like any other spatial strategy and form, if read as texts, may allow for the eliciting, if even partially, of the importance of place to people's sense of identity. The paper has therefore sought to contribute to the growing body of literature on place making and contestation, by looking at the various inscriptions (such as murals and graffiti) seen throughout Trench Town's landscape and examining their role in conjuring up positive images of the community's rich heritage as the birthplace of reggae music as opposed to being a rundown violent-riddled inner-city community. While we made some interesting findings, much more work remains to be done on these and other landscape inscriptions as well as the particular but similar experiences of the communities located in West Kingston and their inhabitants. Also of importance is the particular ways new cultural industries, like music-based tourism, have transformed local places both materially and discursively.

\section{References}

[1] D. Ley and R. Cybriwsky, "Urban graffiti as territorial markers," Annals of the Association of American Geographers, vol. 64, no. 4, pp. 491-505, 1974. 
[2] M. Foucault, Power/Knowledge, Knopf Doubleday, New York, NY, USA, 1980.

[3] M. de Certeau and S. F. Rendall, The Practice of Everyday Life, University of California Press, Berkeley, Calif, USA, 1984.

[4] D. Massey, A Global Sense of Place: From Space, Place and Gender, University of Minnesota Press, Minneapolis, Minn, USA, 1994.

[5] D. Mitchell, "The end of public space? People's Park, definitions of the public, and democracy," Annals -Association of American Geographers, vol. 85, no. 1, pp. 108-133, 1995.

[6] T. Cresswell, In Place/Out of Place: Geography, Ideology, and Transgression, University of Minnesota Press, Minneapolis, Minn, USA, 1996.

[7] D. Alderman, "Writing on the Graceland wall: on the importance of authorship in pilgrimage landscapes," Tourism Recreation Research, vol. 27, no. 2, pp. 27-34, 2002.

[8] R. Jaffe, K. Rhiney, and C. Francis, "Throw word: graffiti, space and power in Kingston, Jamaica," Caribbean Quarterly, vol. 58, no. 1, pp. 1-20, 2012.

[9] K. Rhiney, "Text and textuality," in Encyclopedia of Human Geography, B. Wharf, Ed., pp. 482-484, Sage, London, UK, 2010.

[10] C. G. Clarke, "Population pressure in Kingston, Jamaica: a study of unemployment and overcrowding," Transactions of the Institute of British Geographers, vol. 38, no. 1, pp. 165-182, 1966.

[11] C. G. Clarke, Decolonizing the Colonial City: Urbanization and Stratification in Kingston, Jamaica, Oxford University Press, Oxford, UK, 2006.

[12] S. Stanley-Niaah, "Kingstons's Dancehall: a story of space and celebration," Space and Culture, vol. 7, no. 1, pp. 102-118, 2004.

[13] L. A. Eyre, "Political violence and urban geography in Kingston, Jamaica," Geographical Review, vol. 74, no. 1, pp. 24 37, 1984.

[14] A. Eyre, "The effects of political terrorism on the residential location of the poor in the Kingston Urban Region, Jamaica, West Indies," Urban Geography, vol. 7, no. 3, pp. 227-242, 1996.

[15] M. Figueroa and A. Sives, "Garrison politics and criminality in Jamaica: does the 1997 election represent a turning point?" in Understanding Crime in Jamaica: New Challenges for Public Policies, A. Harriott, Ed., pp. 63-89, Univeristy of the West Indies Press, Kingston, Jamaica, 2003.

[16] R. Kinlocke, "Fear of crime, demographic identity and gated communities in the Kingston Metropolitan Area," in Proceedings of the Annual Meeting of the Association of American Geographers, Boston, Mass, USA, April 2008.

[17] M. Crang, "Rhythms of the city: temporalised space and motion," in Geographies of Temporality, J. May and N. Thrift, Eds., pp. 187-207, Routledge, London, UK, 2001.

[18] P. Sommerville and A. Steele, Eds., Race, Housing and Social Exclusion, Jessica Kingsley Publishers, London, UK, 2002.

[19] D. R. Dodman, "Feelings of belonging? young people's views of their surroundings in kingston, Jamaica," Children's Geographies, vol. 2, no. 2, pp. 185-198, 2004.

[20] H. Lee, Le Premier Rasta, Flammarion, Paris, France, 1999.

[21] O. Patterson, The Children of Sisyphus, Hutchinson, London, UK, 1964.

[22] P. Baker, Blood Posse, St. Martin Griffin, New York, NY, USA, 1994.

[23] D. Blake, Shower Posse: The Most Notorious Jamaican Criminal Organisation, Diamon Publishing, New York, NY, USA, 2002.
[24] M. Figueroa, "An assessment of overvoting in Jamaica," Social \& Economic Studies, vol. 34, no. 3, pp. 71-106, 1985.

[25] M. Figueroa and A. Sives, "Homogenous voting, Electoral manipulation and the 'Garrison' process in postindependence Jamaica," Commonwealth and Comparative Politics, vol. 40, no. 1, pp. 81-108, 2002.

[26] R. Cruse, L'Antimonde caribéen, entre les amériques et le monde [Thèse de doctorat], Université d'Artois, Arras, France, 2009.

[27] E. Le Franc, Ed., Consequences of Structural Adjustment: A Review of the Jamaican Experience, Canoe Press, Kingston, Jamaica, 1994.

[28] M. Davis, Planet of Slums, Verso, London, UK, 2006.

[29] P. Anderson and M. Witter, "Crisis, adjustment \& social change," in Consequences of Structural Adjustment-A Review of the Jamaican Experience, E. LeFranc, Ed., pp. 1-55, Canoe Press, Kingston, Jamaica, 1994.

[30] N. Stolzoff, Wake the Town and Tell the People, Dancehall Culture in Jamaica, Duke University Press, London, UK, 2000.

[31] S. Davis and P. Simon, Reggae International, Thames and Hudson, London, UK, 1983.

[32] S. Barrow and P. Dalton, Reggae: The Rough Guide, Rough Guide, London, UK, 1997.

[33] M. Keith and S. Pile, Eds., Place and the Politics of Identity, Routledge, London, UK, 1993.

[34] D. Massey, "Spaces of politics," in Human Geography Today, D. Massey, J. Allen, and P. Sarre, Eds., pp. 279-294, Polity Press, Cambridge, UK, 1999.

[35] P. Hubbard, R. Kitchin, and G. Valentine, Eds., Key Thinkers on Space and Place, Sage, London, UK, 2004.

[36] K. Cox, "Concepts of space, understanding in human geography, and spatial analysis," Urban Geography, vol. 16, pp. 304326, 1995.

[37] T. F. Gieryn, "A space for place in sociology," Annual Review of Sociology, vol. 26, pp. 463-496, 2000.

[38] A. Gupta and J. Ferguson, "Beyond "Culture": space, identity, and the politics of difference," Cultural Anthropology, vol. 7, no. 1, pp. 6-23, 1992.

[39] J. Agnew, "Representing space: space, scale and culture in social science," in Place/Culture/Representation, J. Duncan and D. Ley, Eds., pp. 251-270, Routledge, London, UK, 1993.

[40] S. Hoelscher, "Making place, making race: performances of whiteness in the Jim Crow South," Annals of the Association of American Geographers, vol. 93, no. 3, pp. 657-686, 2003.

[41] M. Boyer, The City of Collective Memory: Its Historical Imagery and Architectural Entertainments, MIT Press, Cambridge, Mass, USA, 1994.

[42] D. Massey, "Talking of space-time," Transactions of the Institute of British Geographers, vol. 26, no. 2, pp. 257-261, 2001.

[43] J. Duncan, The City as Text: The Politics of Landscape Interpretation in the Kandyan Kingdom, Cambridge University Press, New York, NY, USA, 1990.

[44] D. Bruno and M. Wilson, Eds., Inscribed Landscapes: Marking and Making Place, University of Hawaii Press, Honolulu, Hawaii, USA, 2002.

[45] T. Moreau and D. H. Alderman, "Graffiti hurts and the eradication of alternative landscape expression," Geographical Review, vol. 101, no. 1, pp. 106-124, 2011.

[46] V. Goldman, Exodus: The Making and Meaning of Bob Marley and the Wailers' Album of the Century, Aurum Press, London, UK, 2006.

[47] T. Malcolm, "Trench town culture yard fights for survival," Jamaica Gleaner, 2008, http://www.jamaicagleaner.com/ gleaner/20080212/ent/ent1.html. 
[48] G. J. Ashworth and B. Goodall, Eds., Marketing Tourism Places, Routledge, London, UK, 1990.

[49] J. Urry, The Tourist Gaze, Sage, London, UK, 1990.

[50] Z. U. Ahmed, "The influence of the components of a state's tourist image on product positioning strategy," Tourism Management, vol. 12, no. 4, pp. 331-340, 1991.

[51] M. Sheller, Consuming the Caribbean, Routledge, London, UK, 2003.

[52] D. Timothy and S. Boyd, Heritage Tourism, Pearson, Harlow, UK, 2003.

[53] M. Barke and K. Harrop, "Selling the industrial town: identity, image and illusion," in Place Promotion-The Use of Publicity and Marketing to Sell Towns and Regions, J. R. Gold and S. V. Ward, Eds., pp. 93-114, John Wiley \& Sons, Chichester, UK, 1994.

[54] A. Schöllmann, H. C. Perkins, and K. Moore, "Intersecting global and local influences in urban place promotion: the case of Christchurch, New Zealand," Environment and Planning A, vol. 32, no. 1, pp. 55-76, 2000.

[55] M. Sheller and J. Urry, Eds., Tourism Mobilities: Places to Play, Places in Play, Routledge, London, UK, 2004.

[56] S. C. Larsen, "Negril in the news: content analysis of a contested paradise," Caribbean Geography, vol. 15, no. 1, pp. 35-58, 2008.

[57] C. Bell and J. Lyall, Putting Our Town on the Map -Local Claims to Fame in New Zealand, Harper Collins, Auckland, New Zealand, 1995.

[58] B. Chevannes, Rastafari, Roots and Ideology, University of the West Indies Press, Kingston, Jamaica, 1994.

[59] S. King, T. Barry, B. Bays, and P. Foster, Reggae, Rastafari and the Rhetoric of Social Control, University Press of Mississippi, Ridgewood Road Jackson, Miss, USA, 2002.

[60] J. Niaah, "Absent Father(s), Garvey's scattered children and the Back to Africa Movement," in Negotiating Modernity: Africa'S Ambivalent Experience, E. S. Macamo, Ed., pp. 19-43, Zed Books, London, UK, 2005.

[61] O. Gray, Radicalism and Social Change in Jamaica, 1960-1972, University of Tennessee Press, Knoxville, Tenn, USA, 1991.

[62] O. Gray, Demeaned but Empowered: The Social Power of the Urban Poor in Jamaica, University of the West Indies Press, Kingston, Jamaica, 2004.

[63] D. MacCannell, "Staged authenticity: arrangements of social space in tourist settings," American Journal of Sociology, vol. 79, pp. 589-603, 1973.

[64] P. L. Pearce, The Social Psychology of Tourist Behavior, Pergamon Press, Elmsford, NY, USA, 1982.

[65] S. Beeton, "Rural tourism in Australia-has the gaze altered? Tracking rural images through film and tourism promotion," International Journal of Tourism Research, vol. 6, no. 3, pp. 125-135, 2004.

[66] W. Frost, "Braveheart-ed Ned Kelly: historic films, heritage tourism and destination image," Tourism Management, vol. 27, no. 2, pp. 247-254, 2006.

[67] F. Di Cesare, L. D’Angelo, and G. Rech, "Films and Tourism: understanding the nature and intensity of their cause-effect relationship," Tourism Review International, vol. 13, no. 2, pp. 103-111, 2009.

[68] N. Macionis and B. Sparks, "Film-induced tourism: an incidental experience," Tourism Review International, vol. 13, no. 2, pp. 93-101, 2009.

[69] C. Gibson and J. Connell, Music and Tourism: On the Road Again, Multilingual Matters, Ontario, Canada, 2005.

[70] F. Coffey, The Complete Idiot's Guide to Elvis, Alpha Books, New York, NY, USA, 1997. 


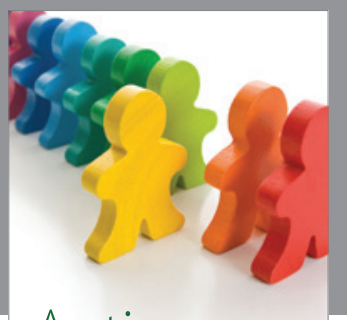

Autism

Research and Treatment
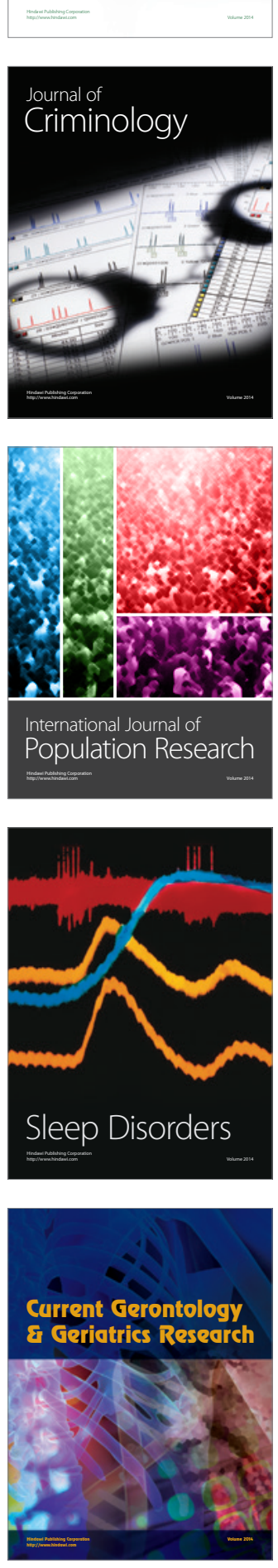
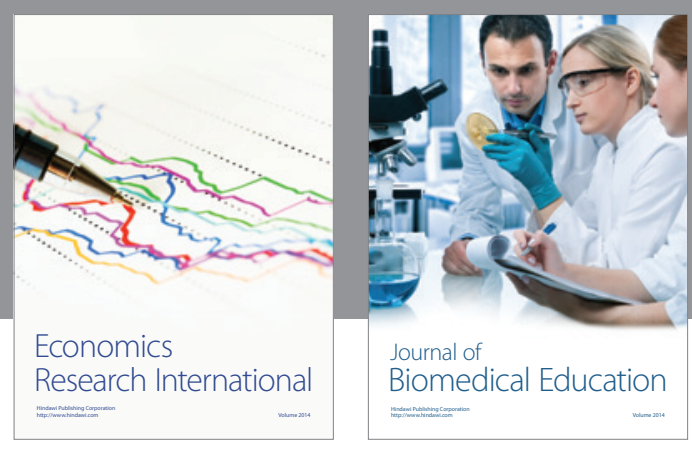

Journal of

Biomedical Education

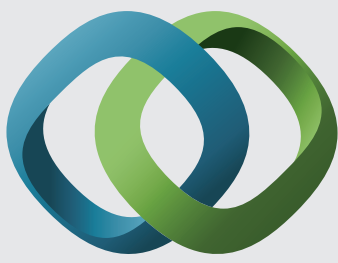

\section{Hindawi}

Submit your manuscripts at

http://www.hindawi.com
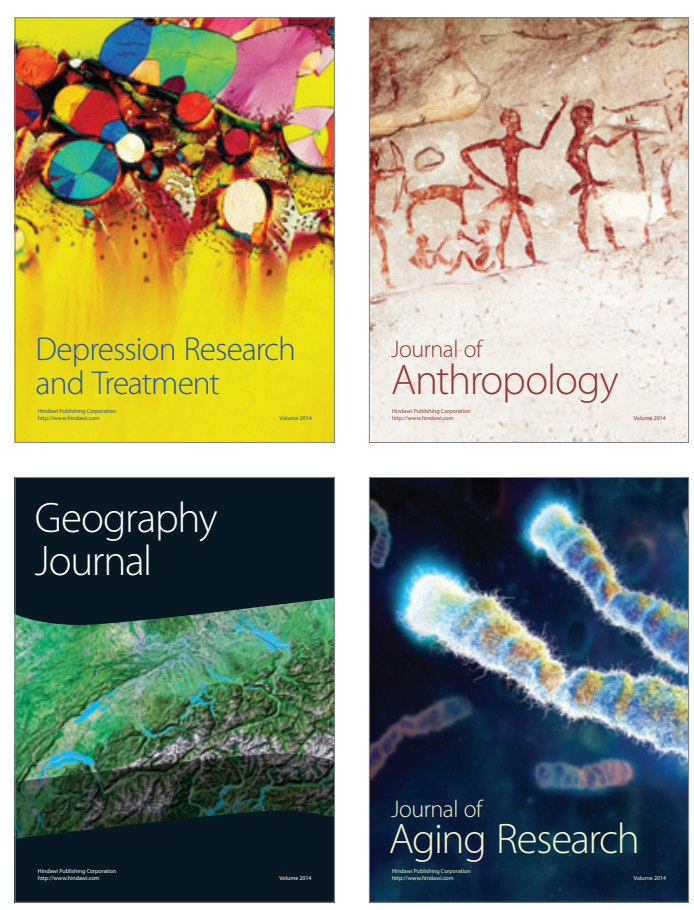

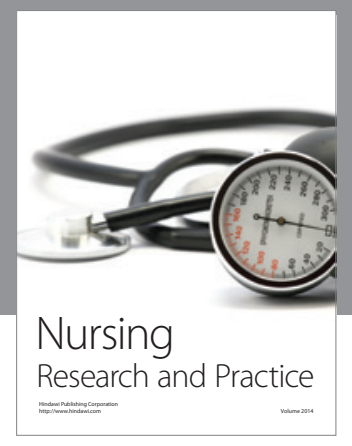

Nursing

Research and Practice

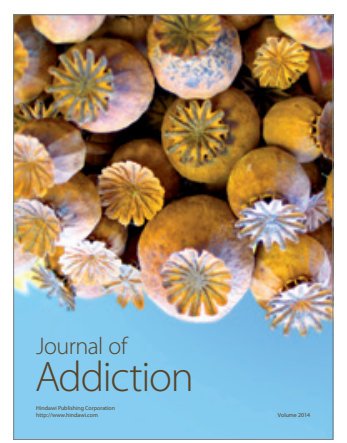

Child Development

Research

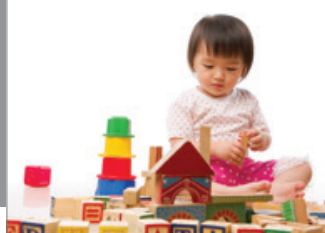

迥
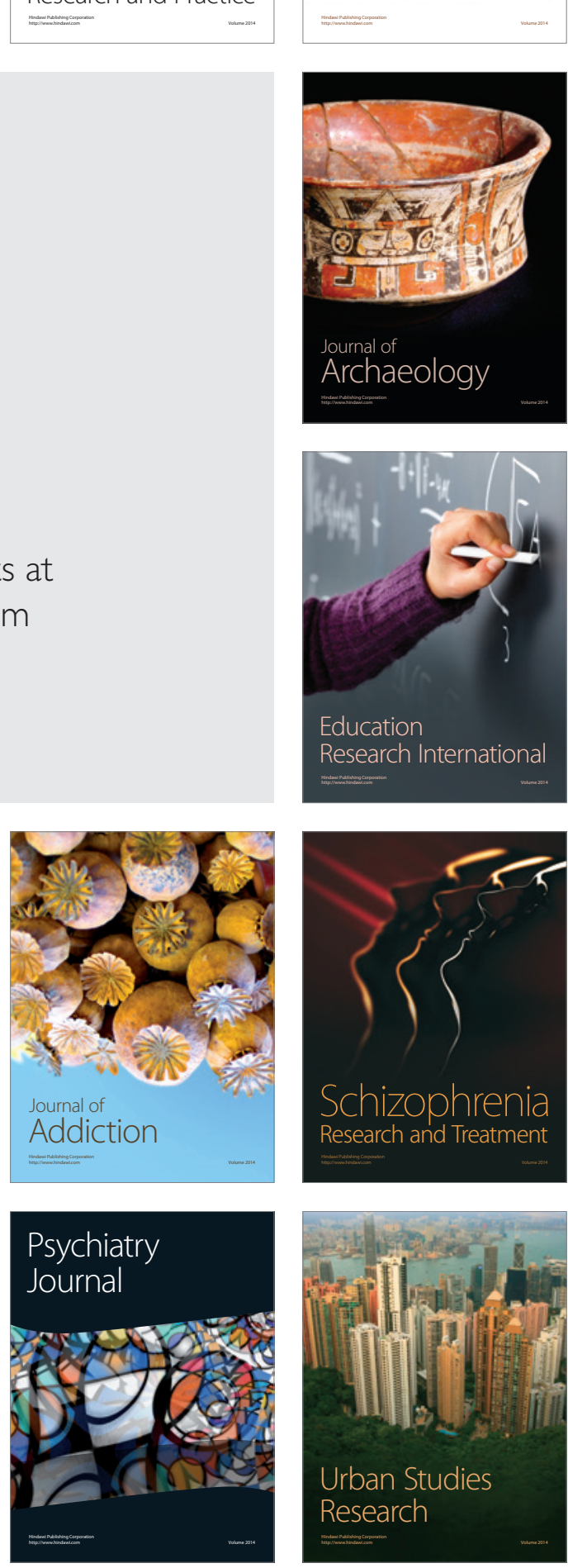